\title{
PENGARUH MOTIVASI KERJA, SIKAP KERJA DAN KEPEMIMPINAN TRANSFORMASIONAL TERHADAP KINERJA PEGAWAI DI SEKRETARIAT DAERAH KABUPATEN LABUHANBATU SELATAN
}

\author{
${ }^{1}$ Lia Ulfayani, ${ }^{2}$ Sumardi, ${ }^{3}$ Yance Irawan Nasution, ${ }^{4}$ Yemki Satria, ${ }^{5}$ Herinov Helfi \\ $1,2,3,4,5$ Universitas Islam Sumatera Utara \\ llia.ulfayani@gmail.com, ${ }^{2}$ sumardi.mm@gmail.com, ${ }^{3}$ yance.irawan@gmail.com, ${ }^{4}$ yemkia.satria@gmail.com, \\ ${ }^{5}$ herinov.helfi@gmail.com
}

\begin{abstract}
Problem of this study how influence of job motivation on performance. How influence of work attitude on performance. How influence of transformational leadership on performance. How influence job motivation, work attitude and transformational leadership on performance. The purpose of this study to determine and analyze the effect of job motivation on performance. Determine and analyze the effect of work attitude on performance. Determine and analyze the effect of transformational leadership on performance. Determine and analyze the effect of job motivation, work attitude and transformational leadership on performance. Sample in the study is 36 employees. Data analysis techniques used in this study is descriptive analyze and multiple linear regression analysis. The results of the study indicate job motivation variable has a positive and significant effect on performance. work attitude variable has a positive and significant effect on performance. transformational leadership variable has a positive and significant effect on performance. Job motivation, work attitude and transformational leadership variable has a positive and significant effect on performance.
\end{abstract}

Keywords : Job motivation, Work attitude, Transformational leadership, Performance.

ABSTRAK : Rumusan masalah dalam penelitian ini adalah apakah ada pengaruh motivasi kerja terhadap kinerja. Apakah ada pengaruh sikap kerja terhadap kinerja. Apakah ada pengaruh kepemimpinan transformasional terhadap kinerja. Apakah ada pengaruh motivasi kerja, sikap kerja dan kepemimpinan transformasional terhadap kinerja. Tujuan penelitian ini adalah untuk mengetahui dan menganalisis pengaruh motivasi kerja terhadap kinerja. Untuk mengetahui dan menganalisis pengaruh sikap kerja terhadap kinerja. Untuk mengetahui dan menganalisis pengaruh kepemimpinan transformasional terhadap kinerja. Untuk mengetahui dan menganalisis pengaruh motivasi kerja, sikap kerja dan kepemimpinan transformasional terhadap kinerja. Sampel dalam penelitian ini berjumlah 34 orang pegawai. Teknik analisis data yang digunakan dalam penelitian ini adalah analisis deskriptif dan analisis regresi linier berganda. Hasil penelitian ini menjelaskan bahwa variabel motivasi kerja berpengaruh positif dan signifikan terhadap kinerja. Variabel sikap kerja berpengaruh positif dan signifikan terhadap kinerja. Variabel kepemimpinan transformasional berpengaruh positif dan signifikan terhadap kinerja. Variabel motivasi kerja, sikap kerja dan kepemimpinan transformasional berpengaruh positif dan signifikan terhadap kinerja.

Kata kunci : Motivasi kerja, Sikap kerja, Kepemimpinan transformasional, Kinerja Kompetensi, Budaya kerja, Kepuasan kerja, Kinerja

\section{Pendahuluan}

Manusia adalah sumber daya organisasi yang memegang peranan penting dalam segala aktifitas di dalamnya, baik itu organisasi swasta ataupun organisasi publik karena manusialah yang mengendalikan seluruh aktifitas sumber daya manusia dan sumber daya lainnya. Dibandingkan dengan faktor lain, sumber daya manusia merupakan aset yang paling berharga. Peranan sumber daya manusia atau pegawai akan sangat menentukan keberhasilan atau kegagalan organisasi dalam mencapai visi dan 
misi yang telah ditetapkan.

Untuk wewujudkan visi dan misi yang telah ditetapkan maka Sekretariat Daerah Kabupaten Labuhanbatu Selatan harus mempunyai pegawai yang terampil, cekatan, jujur, inovatif, kreatif dalam bekerja. Kinerja didefinisikan sebagai suatu keseluruhan kemampuan seseorang untuk bekerja sedemikian rupa sehingga mencapai tujuan kerja secara optimal dan berbagai sasaran yang telah diciptakan dengan pengorbanan yang secara rasio lebih kecil dibandingkan dengan hasil yang dicapai, dengan indikatornya kuantitas kerja, kualitas kerja, pemanfaatan waktu, dan kerjasama, Hasibuan (2013:44).

Masalah kinerja pegawai dalam hal ini Aparatur Sipil Negara (ASN) di Sekretariat Daerah Kabupaten Labuhanbatu Selatan mempunyai fenomena masalah yang hampir sama yang dihadapi oleh instansi pemerintah di Indonesia. Penulis mengambil gambaran umum tentang fenomena masalah kinerja ASN menurut Ivan Taufiza (2014), Pemerintah selama ini kesulitan menggenjot kinerja ASN guna menyediakan layanan publik terbaik akibat menghadapi ketidakseimbangan dalam 3 (tiga) masalah utama, pertama adalah ketidakseimbangan keahlian atau kombinasi keahlian (skill-mix), yakni tingkat pelatihan dan pengembangan ASN tidak sesuai antar dengan keahlian yang dibutuhkan oleh Negara. Ketidakseimbangan skill-mix itu menyebabkan keahlian ASN secara umum rendah sehingga kinerja ASN pun menjadi lemah. Kedua, adalah ketidakseimbangan distribusi (distribution imbalance), yaitu tidak seimbang secara geografis dan peran institusi manajemen ASN yang terkait. Dia mengatakan proses rekruitmen ASN mayoritas terpusat di kota-kota provinsi, padahal Indonesia merupakan negara kepulauan yang sangat luas. Distribusi yang tidak seimbang juga ditemukan pada tidak meratanya penyediaan fasilitas rekruitmen, pelatihan dan pengembangan ASN. Ketiga, ketidakseimbangan sarana pendukung yaitu kurangnya tenaga instruktur yang berkualitas, aplikasi teknologi yang rendah, kompetensi aparat terkait, jaringan informasi serta jumlah fasilitas yang terbatas. Praktik kerja atau onthe-job training untuk mendapatkan keterampilan sesuai dengan yang dibutuhkan juga masih minim.

Untuk mengatasi persoalan tersebut, menurut Ivan diperlukan kebijakan mendasar, seperti alokasi dana anggaran secara lebih adil, untuk tujuan yang terukur dan pembagian kerja yang jelas. Dia menilai harus ada prioritas kepada strategi promosi, manajemen pelatihan, evaluasi kinerja, administrasi finansial dan kontrak kinerja. Salah satu langkah terobosan misalnya dengan pemberian otonomi, wewenang dan insentif kepada pihak swasta dalam pengembangan fasilitas pelatihan dan pengembangan. Selain dari pada itu pemerintah harus berani melakukan reformasi struktur anggaran, untuk skema penghargaan, dan perbaikan remunerasi. Dia mengatakan keterlibatan pemangku kepentingan dalam pengambilan keputusan dan reformasi manajemen ASN sangat penting.

Pemerintah bersama dengan DPR, perusahaan jasa asuransi, Universitas, serta kelompok profesional secara berkesinambungan perlu menciptakan standar profesi, menjalankan pelatihan berkelanjutan, dan bersama-sama mengembangkan kebijakan dan proses ASN. Dimana ASN sebagai abdi negara, sering disalahkan tanpa mendapatkan perlindungan yang layak dari pemerintah sendiri. Oleh karena itu, kini saatnya kabinet kerja serius melakukan investasi meningkatkan kemampuan, daya saing dan kesejahteraan ASN.

Berbagai macam hambatan pegawai di instansi pasti akan ditemui oleh para individu organisasi untuk bisa bekerja dengan baik sehingga kinerja mereka dapat diterima dengan baik oleh instansi dan masyarakat yang memerlukan. Salah satu faktor tersebut adalah motivasi kerja. Teori dari Siagian (2016:77) menyatakan motivasi adalah daya pendorong yang mengakibatkan seseorang mau dan rela mengerahkan kemampuan dalam bentuk keahlian atau keterampilan, tenaga dan waktunya untuk menyelenggarakan berbagai kegiatan yang menjadi tanggung jawabnya dalam rangka pencapaian tujuan organisasi. Seorang yang memiliki motivasi yang rendah mereka cenderung untuk memperlihatkan upaya yang tidak maksimal dalam melaksanakan pekerjaannya, sehingga semakin tinggi motivasi yang dimiliki oleh individu sebagai pegawai maka dapat meningkatkan kinerja pegawai itu sendiri. Dengan demikian, setiap organisasi perlu mengetahui apa yang menjadi motivasi para pegawainya, sebab faktor tersebut dapat menjadi salah satu faktor yang menentukan tinggi atau rendahnya motivasi kerja seorang pegawai dalam melaksanakan pekerjaan. Hasil penelitian dari Agus Marimin (2011), Milka et.al (2015), Nisyak et.al (2016), Noviansyah (2011), Nuraini Latief (2017) dan Nuraini 
Latief (2017), kesemuanya menyatakan bahwa motivasi berpengaruh signifikan terhadap kinerja. Perbedaan hasil penelitian dalam menganalisis pengaruh motivasi terhadap kinerja di tunjukkan pada studi penelitian terdahulu yang dilakukan Anak Agung et.al (2012); dan Raden Yohanes Luhur (2014), yang menyatakan bahwa motivasi berpengaruh tidak signifikan terhadap kinerja.

Faktor lainnya yang mempengaruhi kinerja pegawai di Sekretariat Daerah Kabupaten Labuhanbatu Selatan adalah sikap kerja. Dimana sikap kerja merupakan sikap seseorang terhadap pekerjaannya yang mencerminkan pengalaman yang menyenangkan dan tidak menyenangkan dalam pekerjaannya serta harapan-harapannya terhadap pengalaman masa depan. Sikap kerja dapat dijadikan indikator dalam sebuah pekerjaan dapat berjalan lancar atau tidak, masalah antar pegawai ataupun atasan dapat mengakibatkan terabaikannya sikap kerja. Hasil penelitian terdahulu dari Chres F.P Laoh et.al (2016), Famella et.al (2015), Fonny Corryda Rahayu (2013), dan Alias et.al (2018), kesemuanya menarik kesimpulan sikap kerja berpengaruh positif dan signifikan terhadap kinerja. Sementara hasil penelitian terdahulu dari Rd. Kresna et.al (2017), menarik kesimpulan sikap kerja berpengaruh negati dan tidak terhadap kinerja. Tidak konsistennya dari penelitian terdahulu tersebut sehingga peneliti tertarik melakukan penelitian lanjutan terhadap pegawai di Sekretariat Daerah Kabupaten Labuhanbatu Selatan.

Selain motivasi dan sikap kerja yang dapat mempengaruhi kinerja, maka kepemimpinan transformasional juga diperlukan dalam meningkatkan kinerja pegawai di Sekretariat Daerah Kabupaten Labuhanbatu Selatan. Esensi pokok kepemimpinan adalah cara untuk mempengaruhi orang lain dalam mencapai tujuan organisasi, Sudarmanto (2014:133). Kepemimpinan merupakan tulang punggung pengembangan organisasi karena tanpa adanya kepemimpinan yang baik akan sulit untuk mencapai tujuan organisasi. Apalagi pada saatsaat sekarang ini di mana semua serba terbuka, kepemimpinan yang dibutuhkan adalah kepemimpinan yang bisa memberdayakan pegawainya. Menurut Mangkunegara (2016:55), kepemimpinan transformasional merupakan gaya kepemimpinan yang berupaya mentransformasikan nilai-nilai yang dianut oleh bawahan untuk mendukung visi dan tujuan organisasi. Melalui transformasi nilai-nilai tersebut, diharapkan hubungan baik antar anggota organisasi dapat dibangun sehingga muncul iklim saling percaya diantara anggota organisasi.

Kepemimpinan transformasional pada prinsipnya memotivasi bawahan untuk berbuat lebih baik dari apa yang bisa dilakukan, dengan kata lain dapat meningkatkan kepercayaan atau keyakinan diri bawahan yang akan berpengaruh terhadap peningkatan kinerja. Menurut Mamik (2010:88) dalam Apriyanto dan Satrio (2015:33) indikator kepemimpinan transformasional dapat diukur melalui orientasi tugas, orientasi hubungan, dan kekuasaan jabatan. Bukti penelitian terdahulu menjelaskan bahwa kepemimpinan transformasional berpengaruh positif dan signifikan terhadap kinerja adalah penelitian dari Apriyanto dan Satrio (2015); Albert Apoi and Hamrila Binti Abdul Latip (2019); Endah Mujiarsih dan Sutrisno, (2003); Yusuf Musa, Sani Danjuma, Fadele Ayotunde Alaba (2018), dan Munawaroh (2011). Perbedaan hasil penelitian dalam menganalisis pengaruh kepemimpinan transformasional terhadap kinerja di tunjukkan pada studi penelitian terdahulu yang dilakukan Wahyu Budi Priyanto (2016); Weiping Jiang, Xianbo Zhao, Jiangbin Ni (2017), yang menyatakan bahwa kepemimpinan transformasional berpengaruh positif dan tidak signifikan terhadap kinerja. Permasalahan kepemimpinan transformasional di Sekretariat Daerah Kabupaten Labuhanbatu Selatan diantaranya pembagian tugas ke bawahan terkadang masih kurang merata, komunikasi antara atasan dengan bawahan masih perlu perhatian, karena masih ada pegawai yang takut untuk menyampaikan permasalahan yang terkait pada pembagian tugas.

\subsection{Rumusan Masalah}

Berdasarkan indentifikasi dan batasan masalah tersebut diatas, maka penulis merumuskan masalah dalam penelitian ini yaitu

1) Apakah ada pengaruh motivasi kerja terhadap kinerja pegawai di Sekretariat Daerah Kabupaten Labuhanbatu Selatan.

2) Apakah ada pengaruh kepemimpinan transformasional terhadap kinerja pegawai di Sekretariat Daerah Kabupaten Labuhanbatu Selatan 
3) Apakah ada pengaruh etos kerja terhadap kinerja pegawai di Sekretariat Daerah Kabupaten Labuhanbatu Selatan

4) Apakah ada pengaruh motivasi kerja, sikap kerja, dan kepemimpinan transformasional terhadap kinerja pegawai di Sekretariat Daerah Kabupaten Labuhanbatu Selatan.

\subsection{Batasan Masalah}

Mengingat ada beberapa permasalahan yang teridentifikasi dan dikarenakan waktu serta kemampuan yang penulis miliki dalam melaksanakan penelitian ini masih kurang, maka dari masalah-masalah yang teridentifikasi tersebut penulis mencoba membatasi masalah yang akan diteliti hanya pada masalah motivasi kerja, sikap kerja, kepemimpinan transformasional dan kinerja pegawai.

\subsection{Hipotesis}

Berdasarkan pada kerangka konseptual di atas, maka hipotesis dalam penelitian ini adalah

1) Ada pengaruh motivasi kerja terhadap kinerja pegawai di Sekretariat Daerah Kabupaten Labuhanbatu Selatan.

2) Ada pengaruh sikap kerja terhadap kinerja pegawai di Sekretariat Daerah Kabupaten Labuhanbatu Selatan.

3) Ada pengaruh kepemimpinan transformasional terhadap kinerja pegawai di Sekretariat Daerah Kabupaten Labuhanbatu Selatan.

4) Ada pengaruh motivasi kerja, sikap kerja dan kepemimpinan transformasional terhadap kinerja pegawai di Sekretariat Daerah Kabupaten Labuhanbatu Selatan.

\subsection{Tujuan Penelitian}

Tujuan penelitian ini adalah :

1) Untuk mengetahui dan menganalisis pengaruh motivasi kerja terhadap kinerja pegawai di Sekretariat Daerah Kabupaten Labuhanbatu Selatan.

2) Untuk mengetahui dan menganalisis pengaruh kepemimpinan transformasional terhadap kinerja pegawai di Sekretariat Daerah Kabupaten Labuhanbatu Selatan

3) Untuk mengetahui dan menganalisis pengaruh etos kerja terhadap kinerja pegawai di Sekretariat Daerah Kabupaten Labuhanbatu Selatan

4) Untuk mengetahui dan menganalisis pengaruh motivasi kerja, sikap kerja, dan kepemimpinan transformasional terhadap kinerja pegawai di Sekretariat Daerah Kabupaten Labuhanbatu Selatan.

\section{Metode Penelitian}

\subsection{Populasi}

Menurut Sugiyono (2011:90) populasi adalah wilayah generasi yang terdiri dari atas objek/subjek yang mempunyai kualitas karakteristik tertentu yang disajikan oleh peneliti untuk dipelajari dan kemudian ditarik kesimpulannya. Berdasarkan defenisi tersebut, maka populasi dalam penelitian ini adalah pegawai di Bagian Hubungan Masuarakat dan Protokol Sekretariat Daerah Kabupaten Labuhanbatu Selatan yang berjumlah 34 orang. Populasi ini tidak termasuk Sekda, Asisten dan peneliti, dengan rincian sebagai berikut :

Tabel 1. Distribusi Populasi Penelitian Berdasarkan Bagian

\begin{tabular}{|c|l|c|}
\hline No & \multicolumn{1}{|c|}{ Keterangan/Bagian } & Jumlah (Orang) \\
\hline 1 & $\begin{array}{l}\text { Sub Bagian Protokol dan Tata Usaha } \\
\text { Pimpinan }\end{array}$ & 13 \\
\hline 2 & $\begin{array}{l}\text { Sub Bagian Hubungan Antar Lembaga, } \\
\text { Informasi dan Data Elektronik }\end{array}$ & 11 \\
\hline 3 & $\begin{array}{l}\text { Sub Bagian Pemberitaan, Penerbitan dan } \\
\text { Dokumentasi }\end{array}$ & 10 \\
\hline \multicolumn{2}{|c|}{ Total } \\
\hline
\end{tabular}

\subsection{Sampel}

Menurut Sugiyono (2001:93), sampel adalah elemen-elemen populasi yang dipilih atas dasar kemampuan mewakilinya. Untuk menjadi pedoman jika subjeknya atau populasinya kurang dari 100, maka lebih baik diambil semua sebagai sampel, sehingga penelitiannya merupakan penelitian populasi. Selanjutnya jika jumlah subjeknya atau populasinya besar atau lebih dari 100, maka dapat diambil persentasenya. Dengan teknik penarikan sampel secara total sampling, maka sampel dalam penelitian ini seluruh populasi yaitu 34 orang pegawai di Bagian Hubungan Masuarakat dan Protokol Sekretariat Daerah Kabupaten Labuhanbatu Selatan 
Tabel 2. Distribusi Sampel Penelitian Berdasarkan Bagian

\begin{tabular}{|c|c|c|}
\hline $\mathrm{No}$ & Keterangan/Bagian & Jumlah (Orang) \\
\hline 1 & Sub Bagian Protokol dan Tata Usaha Pimpinan & 13 \\
\hline 2 & $\begin{array}{l}\text { Sub Bagian Hubungan Antar Lembaga, } \\
\text { Informasi dan Data Elektronik }\end{array}$ & 11 \\
\hline 3 & $\begin{array}{lrll}\text { Sub } & \text { Bagian } & \text { Pemberitaan, Penerbitan } & \text { dan } \\
\text { Dokumentasi } & & & \end{array}$ & 10 \\
\hline \multicolumn{2}{|r|}{ Total } & 34 \\
\hline
\end{tabular}

Sumber : Bagian Hubungan Masyarakat dan Protokol, 2021

\subsection{Uji Normalitas}

Menurut Duwi Priyatno (2012:144) pengertian dari uji normalitas adalah untuk menguji apakah nilai residual yang dihasilkan dari regresi terdistribusi secara normal atau tidak. Model regresi yang baik adalah yang memiliki nilai residual yang terdistribusi normal. Untuk mengetahui bentuk distribusi data, bisa dilakukan dengan grafik distribusi dan analisis statistik. Pengujian dengan distribusi dilakukan dengan melihat grafik histogram yang membandingkan antara dua observasi dengan distribusi yang mendekati distribusi normal. Distribusi normal akan membentuk satu garis lurus diagonal dan ploating data residual akan dibandingkan dengan garis diagonal. Jika distribusi atau residual normal, maka garis yang menggambarkan data yang sesungguhnya akan mengikuti garis diagonalnya. Uji normalitas dengan grafik dapat dilakukan dengan program SPSS dengan analisis grafik Normal Probability Plot

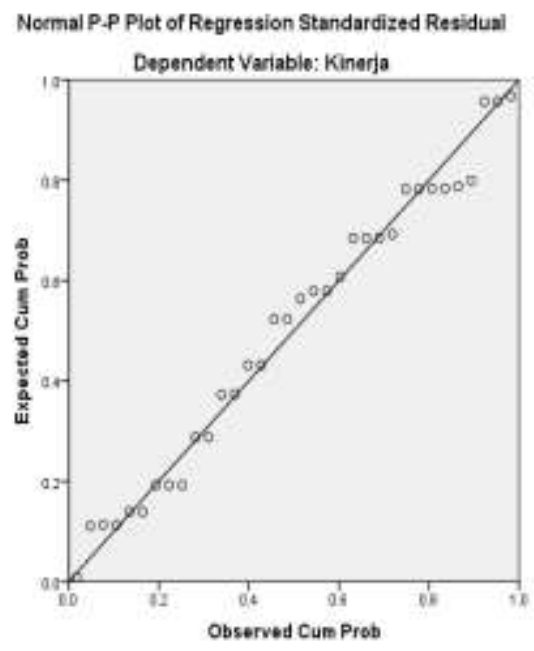

Gambar.1. Uji normalitas data
Berdasarkan gambar 1, diatas terlihat titiktitik dari ploating data residual berada di garis diagonal, hal ini dapat disimpulkan data yang diuji berdistribusi normal.

\subsection{Uji Multikolinieritas}

Salah satu asumsi dari model regresi linier bahwa tidak terjadi korelasi yang signifikan antara variabel bebasnya. Untuk menguji hal tersebut maka diperlukan suatu uji yang disebut uji multikolinieritas. Menurut Duwi Priyatno (2012:151) pengertian multikolinieritas adalah keadaan di mana pada model regresi ditemukan adanya korelasi yang sempurna atau mendekati sempurna antar variabel independen. Pada regresi yang baik seharusnya tidak terjadi korelasi yang sempurna atau mendekati sempurna diantara variabel bebas. Uji multikolinieritas adalah untuk melihat ada atau tidaknya korelasi yang tinggi antara variabelvariabel bebasnya, maka hubungan antara variabel bebas terhadap variabel terikatnya menjadi terganggu. Jika terdapat korelasi yang kuat dimana sesama variabel independen maka konsekuensinya adalah :

a. Koefisien-koefisien regresi menjadi tidak dapat ditaksir

b. Nilai standar error setiap koefisien regresi menjadi tidak terhingga.

Dengan demikian, semakin besar korelasi diantara sesama variabel independen maka kepemimpinan kesalahan dari koefisien regresi semakin besar yang dapat mengakibatkan standar error semakin besar pula. Cara yang digunakan untuk mendeteksi ada tidaknya multikolinieritas adalah dengan melihat besarnya nilai Variance Inflation Factor (VIF). Jika VIF dibawah 10 dan Tolerance Value diatas 0,1 maka tidak terjadi multikolinieritas. 
Tabel 3. Uji multikolinieritas

\begin{tabular}{|l|c|c|}
\hline \multirow{2}{*}{ Variabel } & \multicolumn{2}{c|}{ Collinearity Statistics } \\
\cline { 2 - 3 } & Tolerance & VIF \\
\hline Motivasi kerja & 0.766 & 1.306 \\
\hline Sikap kerja & 0.864 & 1.157 \\
\hline Kepemimpinan transformasional & 0.874 & 1.145 \\
\hline
\end{tabular}

a. Dependent Variable : Kinerja

Berdasarkan Tabel 3 diatas diperoleh nilai Tolerance Value diatas 0.1 yaitu 0.766, 0.864, dan 0.874 , hal ini menunjukan adanya korelasi yang cukup tinggi/kuat antara sesama variabel bebas dan nilai Variance Inflantion Factorrs (VIF) sebesar 1.306, 1.157, dan 1.145, dimana nilai VIF dari ketiga varibel bebas lebih kecil dari 10 dan dapat disimpulkan tidak terdapat multikolinieritas diantara ketiga variabel bebas yang diuji dalam penelitian ini.

\subsection{Uji Autokorelasi}

Uji autokorelasi merupakan pengujian dimana variabel dependen tidak berkorelasi dengan nilai variabel itu sendiri, baik nilai periode sebelumnya maupun nilai periode sesudahnya. Menurut Duwi Priyatno
(2012:172) pengertian dari autokorelasi adalah keadaan di mana pada model regresi ada korelasi antara residual pada periode tertentu $\mathrm{t}$ dengan residual pada periode sebelumnya ( $\mathrm{t}-1)$, model regresi yang baik adalah yang tidak terdapat masalah autokorelasi. Metode pengujian menggunakan uji Durbin-Watson (DW-test). Salah satu ukuran dalam menentukan ada tidaknya masalah autokorelasi dengan uji Durbin-Watson (DW) dengan ketentuan sebagai berikut :

Terjadi autokorelasi positif jika nilai DW dibawah -2 atau DW $<-2$

Tidak terjadi autokorelasi jika nilai DW diantara -2 dan +2 atau $-2<$ DW $<+2$

Terjadi autokorelasi negatif jika nilai DW di atas 2 atau DW $>2$.

Tabel 4. Uji Autokorelasi

\begin{tabular}{|l|c|c|c|c|c|c|}
\hline \multirow{4}{*}{ Model } & \multicolumn{5}{|c|}{ Change Statistics } & \multirow{2}{*}{$\begin{array}{c}\text { Durbin- } \\
\text { Watson }\end{array}$} \\
\cline { 2 - 7 } & $\begin{array}{c}\text { R Square } \\
\text { Change }\end{array}$ & F Change & df1 & df2 & $\begin{array}{c}\text { Sig. F } \\
\text { Change }\end{array}$ & \\
\hline 1 & .650 & 18.604 & 3 & 30 & .000 & 2.052 \\
\hline
\end{tabular}

Berdasarkan Tabel 4 di atas diperoleh nilai Durbin-Watson (DW) sebesar 2.052, nilai ini berada pada kisaran $-2<\mathrm{DW}<+2$, maka dapat disimpulkan bahwa tidak terjadi autokorelasi pada model regresi dalam penelitian ini.

\subsection{Uji Heteroskedastisitas}

Uji heteroskedastisitas bertujuan untuk menguji apakah dalam model regresi terjadi ketidaksamaan variance dari residual satu pengamatan ke pengamatan yang lainnya. Gejala variance yang tidak sama ini disebut dengan heteroskedastisitas, sedangkan adanya gejala residual yang sama dari satu pengamatan ke pengamatan lain disebut dengan homokedastisitas. Menurut Duwi Priyatno (2012:158) pengertian dari heteroskedastisitas adalah dimana dalam model regresi tejadi ketidaksamaan varian dari residual pada suatu pengamatan ke pengamatan yang lain. Model regresi yang baik adalah tidak terjadi heteroskedastisitas. Berbagai macam uji heteroskedastisitas yaitu dengan uji glejser, melihat pola titik-titik pada scatterplots regresi, atau uji koefisien korelasi spearman's.

Uji heteroskedastisitas dapat dilakukan dengan menggunakan grafik scatterplot antara nilai variabel terikat (ZSPRED) dengan residualnya (SRESID), dimana sumbu $X$ adalah yang diprediksi dan sumbu $\mathrm{Y}$ adalah residual. Dasar pengambilan keputusan yang dapat diambil adalah sebagai berikut :

a. Jika pola tertentu seperti titik-titik yang ada membentuk suatu pola yang teratur (bergelombang, melebar kemudian menyempit) maka telah terjadi heteroskedastisitas.

b. Jika tidak ada yang jelas serta titik-titik menyebar diatas dan dibawah angka nol pada sumbu Y maka tidak terjadi heteroskedastisitas 


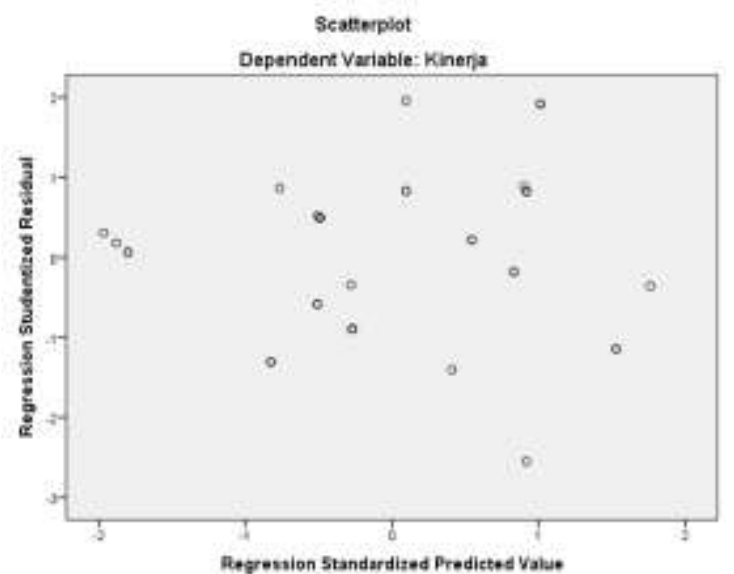

Gambar .2. Uji heteroskedastisitas

Berdasarkan gambar 2, diatas, menunjukkan titik-titik yang menyebar, sehingga dapat disimpulkan tidak terjadi heteroskedastisitas di data penelitian ini.

\section{Uji Hipotesis}

Dalam uji hipotesis ini peneliti akan melihat model persamaan regresi berganda dan akan menguji kebenaran hipotesis baik itu secara partial atau sendiri-sendiri, maupun secara simultan atau bersama-sama, dan untuk memudahkan peneliti dalam pengolahan data, maka digunakan Program Statistical Product and Service Solutions versi 22.00.

\subsection{Analisis Regresi Linier Berganda.}

Analisis regresi linier berganda dalam penelitian ini dapat dilihat dari persamaan regresinya, dan dari hasil pengolahan data diperoleh hasil berikut ini :

Tabel 5. Analisis regresi linier berganda

\begin{tabular}{|l|r|r|r|r|r|}
\hline \multirow{2}{*}{ Model } & \multicolumn{2}{|c|}{$\begin{array}{c}\text { Unstandardized } \\
\text { Coefficients }\end{array}$} & \multirow{2}{*}{$\begin{array}{c}\text { Standardized } \\
\text { Coefficients } \\
\text { Beta }\end{array}$} & \multirow{2}{*}{$\mathrm{t}$} & \multirow{2}{*}{ Sig. } \\
\cline { 2 - 3 } & \multicolumn{1}{c|}{$\mathrm{B}$} & Std. Error & & \\
\hline (Constant) & 6.138 & 5.294 & & 1.160 & .255 \\
\hline Motivasi kerja & .314 & .103 & .377 & 3.059 & .005 \\
\hline Sikap kerja & .211 & .097 & .251 & 2.165 & .038 \\
\hline $\begin{array}{l}\text { Kepemimpinan } \\
\text { transformasional }\end{array}$ & .355 & .087 & .470 & 4.071 & .000 \\
\hline
\end{tabular}

Hasil pengolahan data, 2021

Berdasarkan Tabel 5. diatas dapat dibuat persamaan regresi dalam penelitian ini sebagai berikut:

$$
\mathrm{Y}=6.138+0.314 \mathrm{X}_{1}+0.211 \mathrm{X}_{2}+0.355 \mathrm{X}_{3}
$$

Dari persamaan regresi linier berganda di atas dapat dijelaskan :

1) Nilai kinerja pegawai di Sekretariat Daerah

Kabupaten Labuhanbatu Selatan sebesar 6.138 , yang mana nilai dari variabel dari variabel motivasi kerja, sikap kerja dan kepemimpinan transformasional diabaikan.

2) Nilai koefisien regresi $X_{1}$ (motivasi kerja) mempunyai nilai positif yaitu 0.314 , hal ini menunjukkan bahwa variabel motivasi kerja mempunyai pengaruh yang searah dan positif terhadap kinerja pegawai di Sekretariat Daerah Kabupaten Labuhanbatu Selatan.

3) Nilai koefisien regresi $X_{2}$ (sikap kerja) mempunyai nilai positif yaitu 0.211 , hal ini menunjukkan bahwa variabel sikap kerja mempunyai pengaruh yang searah dan positif terhadap kinerja pegawai di Sekretariat Daerah Kabupaten Labuhanbatu Selatan.

4) Nilai koefisien regresi $X_{3}$ (kepemimpinan transformasional) mempunyai nilai positif yaitu 0.355 , hal ini menunjukkan bahwa variabel kepemimpinan transformasional mempunyai pengaruh yang searah dan positif terhadap kinerja pegawai di Sekretariat Daerah Kabupaten Labuhanbatu Selatan.

\subsection{Pengaruh Motivasi Kerja Terhadap Kinerja Pegawai di Sekretariat Daerah Kabupaten Labuhanbatu Selatan.}

Untuk mengetahui pengaruh motivasi kerja terhadap kinerja pegawai di Sekretariat Daerah Kabupaten Labuhanbatu Selatan digunakan uji$\mathrm{t}$, sedangkan untuk melihat besarnya pengaruh digunakan nilai Beta atau Standardized Coefficient Beta. 
Tabel. 6. Pengaruh motivasi kerja terhadap kinerja

\begin{tabular}{|l|r|r|r|r|r|}
\hline \multirow{2}{*}{ Model } & \multicolumn{2}{|c|}{$\begin{array}{c}\text { Unstandardized } \\
\text { Coefficients }\end{array}$} & \multirow{2}{*}{$\begin{array}{c}\text { Standardized } \\
\text { Coefficients } \\
\text { Beta }\end{array}$} & \multirow{2}{*}{$\mathrm{t}$} & \multirow{2}{*}{ Sig. } \\
\cline { 2 - 3 } & \multicolumn{1}{|c|}{$\mathrm{B}$} & Std. Error & & \\
\hline (Constant) & 6.138 & 5.294 & & 1.160 & .255 \\
\hline Motivasi kerja & .314 & .103 & .377 & 3.059 & .005 \\
\hline
\end{tabular}

a. Dependent Variable : Kinerja

Hasil pengolahan data, 2021

Dari Tabel 6 diatas diperoleh nilai $\mathrm{t}_{\text {hitung }}$ sebesar 3.059. Penelitian ini menggunakan taraf signifikansi $(\alpha: 0.05)$ dan Derajat Kebebasan (DK) dengan ketentuan DK $=\mathrm{n}-2$, atau $34-2$ $=32$. Dengan ketentuan tersebut, diperoleh nilai $t_{\text {tabel }}$ sebesar 2.036. Dengan kriteria hipotesis sebagai berikut :

Jika $t_{\text {hitung }}>t_{\text {tabel }}$, maka $\mathrm{H}_{0}$ ditolak dan $\mathrm{H}_{1}$ diterima.

Jika $t_{\text {hitung }}<\mathrm{t}_{\text {tabel }}$, maka $\mathrm{H}_{0}$ diterima dan $\mathrm{H}_{1}$ ditolak.

Dari hasil pengolahan data diperoleh nilai $t_{\text {hitung }}>t_{\text {tabel }}(3.059>2.036)$ dan nilai signifikasi lebih kecil dari nilai $\alpha: 0.05$ yaitu $0.005<0.05$, sehingga $\mathrm{H}_{0}$ ditolak dan $\mathrm{H}_{1}$ diterima. Artinya variabel motivasi kerja secara partial berpengaruh positif dan signifikan terhadap kinerja pegawai di Sekretariat Daerah Kabupaten Labuhanbatu Selatan. Besarnya pengaruh variabel motivasi kerja terhadap kinerja pegawai di Sekretariat Daerah Kabupaten Labuhanbatu Selatan sebesar 0.377 atau $37.70 \%$.

\subsection{Pengaruh Sikap Kerja Terhadap Kinerja Pegawai di Sekretariat Daerah Kabupaten Labuhanbatu Selatan.}

Untuk mengetahui pengaruh sikap kerja terhadap kinerja pegawai di Sekretariat Daerah Kabupaten Labuhanbatu Selatan digunakan uji$\mathrm{t}$, sedangkan untuk melihat besarnya pengaruh digunakan nilai Beta atau Standardized Coefficient Beta.

Tabel 7. Pengaruh sikap kerja terhadap kinerja

\begin{tabular}{|l|r|r|r|r|r|}
\hline \multirow{2}{*}{ Model } & \multicolumn{2}{|c|}{$\begin{array}{c}\text { Unstandardized } \\
\text { Coefficients }\end{array}$} & $\begin{array}{c}\text { Standardized } \\
\text { Coefficients } \\
\text { Beta }\end{array}$ & \multirow{2}{*}{$\mathrm{t}$} & \multirow{2}{*}{ Sig. } \\
\cline { 2 - 3 } & \multicolumn{1}{|c|}{$\mathrm{B}$} & \multicolumn{1}{|c|}{ Std. Error } & & \\
\hline (Constant) & 6.138 & 5.294 & & 1.160 & .255 \\
\hline Sikap kerja & .211 & .097 & .251 & 2.165 & .038 \\
\hline
\end{tabular}

a. Dependent Variable : Kinerja

Hasil pengolahan data, 2021

Dari Tabel 7 diatas diperoleh nilai $\mathrm{t}_{\text {hitung }}$ sebesar 2.165. Penelitian ini menggunakan taraf signifikansi $(\alpha: 0.05)$ dan Derajat Kebebasan (DK) dengan ketentuan DK $=\mathrm{n}-2$, atau $34-2$ $=32$. Dengan ketentuan tersebut, diperoleh nilai $\mathrm{t}_{\text {tabel }}$ sebesar 2.036. Dengan kriteria hipotesis sebagai berikut :

Jika $t_{\text {hitung }}>t_{\text {tabel }}$, maka $\mathrm{H}_{0}$ ditolak dan $\mathrm{H}_{1}$ diterima.

Jika $\mathrm{t}_{\text {hitung }}<\mathrm{t}_{\text {tabel }}$, maka $\mathrm{H}_{0}$ diterima dan $\mathrm{H}_{1}$ ditolak.

Dari hasil pengolahan data diperoleh nilai $t_{\text {hitung }}>t_{\text {tabel }}(2.165>2.036)$ dan nilai signifikasi lebih kecil dari nilai $\alpha: 0.05$ yaitu $0.038<0.05$, sehingga $\mathrm{H}_{0}$ ditolak dan $\mathrm{H}_{1}$ diterima. Artinya variabel sikap kerja secara partial berpengaruh positif dan signifikan terhadap kinerja pegawai di Sekretariat Daerah Kabupaten Labuhanbatu Selatan. Besarnya pengaruh variabel sikap kerja terhadap kinerja pegawai di Sekretariat Daerah Kabupaten Labuhanbatu Selatan sebesar 0.251 atau $25.10 \%$.

\subsection{Pengaruh Kepemimpinan Transformasional Terhadap Kinerja Pegawai di Sekretariat Daerah Kabupaten Labuhanbatu Selatan.}

Untuk mengetahui pengaruh kepemimpinan transformasional terhadap kinerja pegawai di Sekretariat Daerah Kabupaten Labuhanbatu Selatan digunakan uji-t, sedangkan untuk melihat besarnya pengaruh digunakan nilai Beta atau Standardized Coefficient Beta. 
Tabel. 8. Pengaruh kepemimpinan transformasional kerja terhadap kinerja

\begin{tabular}{|c|c|c|c|c|c|}
\hline \multirow[t]{2}{*}{ Model } & \multicolumn{2}{|c|}{$\begin{array}{c}\text { Unstandardized } \\
\text { Coefficients }\end{array}$} & \multirow{2}{*}{$\begin{array}{c}\text { Standardized } \\
\text { Coefficients } \\
\text { Beta }\end{array}$} & \multirow[t]{2}{*}{$\mathrm{t}$} & \multirow[t]{2}{*}{ Sig. } \\
\hline & $\mathrm{B}$ & Std. Error & & & \\
\hline (Constant) & 6.138 & 5.294 & & 1.160 & .255 \\
\hline $\begin{array}{l}\text { Kepemimpinan } \\
\text { transformasional }\end{array}$ & .355 & .087 & 470 & 4.071 & .000 \\
\hline
\end{tabular}

Hasil pengolahan data, 2021

Dari Tabel 8 diatas diperoleh nilai $\mathrm{t}_{\text {hitung }}$ sebesar 4.071. Penelitian ini menggunakan taraf signifikansi $(\alpha: 0.05)$ dan Derajat Kebebasan (DK) dengan ketentuan DK $=\mathrm{n}-2$, atau $34-2$ $=32$. Dengan ketentuan tersebut, diperoleh nilai $\mathrm{t}_{\text {tabel }}$ sebesar 2.036. Dengan kriteria hipotesis sebagai berikut :

Jika $\mathrm{t}_{\text {hitung }}>\mathrm{t}_{\text {tabel }}$, maka $\mathrm{H}_{0}$ ditolak dan $\mathrm{H}_{1}$ diterima.

Jika $\mathrm{t}_{\text {hitung }}<\mathrm{t}_{\text {tabel }}$, maka $\mathrm{H}_{0}$ diterima dan $\mathrm{H}_{1}$ ditolak.

Dari hasil pengolahan data diperoleh nilai $t_{\text {hitung }}>t_{\text {tabel }}(4.071>2.036)$ dan nilai signifikasi lebih kecil dari nilai $\alpha: 0.05$ yaitu $0.000<0.05$, sehingga $\mathrm{H}_{0}$ ditolak dan $\mathrm{H}_{1}$ diterima. Artinya variabel kepemimpinan transformasional secara partial berpengaruh positif dan signifikan

Tabel 9. Pengaruh motivasi kerja, sikap kerja dan

Tabel 9. Pengaruh motivasi kerja, sikap kerja dan kepemimpinan transformasional terhadap kinerja

\begin{tabular}{|l|l|r|r|r|r|c|}
\hline \multirow{2}{*}{ Model } & & $\begin{array}{c}\text { Sum of } \\
\text { Squares }\end{array}$ & \multicolumn{1}{c|}{ df } & $\begin{array}{c}\text { Mean } \\
\text { Square }\end{array}$ & \multicolumn{1}{c|}{ F } & Sig. \\
\hline \multirow{2}{*}{1} & Regression & 197.108 & 3 & 65.703 & 18.604 & $.000^{\mathrm{a}}$ \\
\cline { 2 - 7 } & Residual & 105.951 & 30 & 3.532 & & \\
\cline { 2 - 7 } & Total & 303.059 & 33 & & & \\
\hline
\end{tabular}

Dependent Variable : Kinerja

Hasil pengolahan data, 2021

Dari Tabel 9. di atas diperoleh nilai $\mathrm{F}_{\text {hitung }}$ sebesar 18.604. Penelitian ini menggunakan taraf signifikansi $(\alpha: 0.05)$ dan Derajat Kebebasan (DK) dengan ketentuan numerator : jumlah variabel -1 atau $4-1=3$, dan jumlah sampel dikurang 4 atau $34-4=30$. Dengan ketentuan tersebut, diperoleh nilai $\mathrm{F}_{\text {tabel }}$ sebesar 3.330. Dengan kriteria pengujian hipotesis sebagai berikut :

Jika $\mathrm{F}_{\text {hitung }}>\mathrm{F}_{\text {tabel }}$, maka $\mathrm{H}_{0}$ ditolak dan $\mathrm{H}_{1}$ diterima.

Jika $\mathrm{F}_{\text {hitung }}<\mathrm{F}_{\text {tabel }}$, maka $\mathrm{H}_{0}$ diterima dan $\mathrm{H}_{1}$ ditolak.

Dari hasil perhitungan diperoleh nilai $\mathrm{F}_{\text {hitung }}$ $>\mathrm{F}_{\text {tabel }}(18.604>3.330)$ dan nilai signifikasi $0.000<0.05$, sehingga $\mathrm{H}_{0}$ ditolak dan $\mathrm{H}_{1}$ diterima. Artinya variabel motivasi kerja, sikap kerja dan kepemimpinan transformasional terhadap kinerja pegawai di Sekretariat Daerah Kabupaten Labuhanbatu Selatan. Besarnya pengaruh variabel kepemimpinan transformasional terhadap kinerja pegawai Sekretariat Daerah Kabupaten Labuhanbatu Selatan sebesar 0.470 atau $47 \%$.

\subsection{Pengaruh Motivasi Kerja, Sikap Kerja dan Kepemimpinan Transformasional Terhadap Kinerja Pegawai Di Sekretariat Daerah Kabupaten Labuhanbatu Selatan}

Untuk mengetahui pengaruh motivasi kerja, sikap kerja dan kepemimpinan transformasional terhadap kinerja pegawai Sekretariat Daerah Kabupaten Labuhanbatu Selatan digunakan ujiF. 
Tabel 10. Model summary ${ }^{\mathrm{b}}$ pengaruh motivasi kerja, sikap kerja dan kepemimpinan transformasional terhadap kinerja

\begin{tabular}{|c|c|c|c|c|}
\hline Model & $\mathrm{R}$ & $R$ Square & $\begin{array}{l}\text { Adjusted } R \\
\text { Square }\end{array}$ & Std. Error of the Estimate \\
\hline 1 & $.806^{\mathrm{a}}$ & .650 & .615 & 1.87928 \\
\hline
\end{tabular}

Hasil pengolahan data, 2021

Besarnya Tabel 10. diatas diperoleh nilai Rsquare $\left(\mathrm{r}^{2}\right)$ sebesar 0.650. Nilai tersebut mempunyai maksud bahwa pengaruh motivasi kerja, sikap kerja dan kepemimpinan transformasional terhadap kinerja pegawai di Sekretariat Daerah Kabupaten Labuhanbatu Selatan sebesar $65 \%$, sedangkan sisanya sebesar $35 \%$ dipengaruhi oleh faktor-faktor lain yang tidak diteliti. Dengan kata lain variabel kinerja pegawai di Sekretariat Daerah Kabupaten Labuhanbatu Selatan dapat diterangkan oleh variabel motivasi kerja, sikap kerja dan kepemimpinan transformasional sebesar $65 \%$, sedangkan sisanya sebesar $35 \%$ disebabkan oleh variabel-variabel lain yang tidak diteliti seperti sikap inovatif, kerjasama, gaya kepemimpinan, fasilitas kerja dan lain sebagainya.

\section{Evaluasi Data}

\subsection{Pengaruh Motivasi Kerja Terhadap Kinerja Pegawai di Sekretariat Daerah Kabupaten Labuhanbatu Selatan.}

Berdasarkan pada hasil penelitian dapat dijelaskan bahwa motivasi kerja berpengaruh positif dan signifikan terhadap kinerja pegawai di Sekretariat Daerah Kabupaten Labuhanbatu Selatan. Hasil penelitian ini sejalan dengan hasil penelitian terdahulu dari Agus Marimin (2011), Milka et.al (2015), Nisyak et.al (2016), Noviansyah (2011), Nuraini Latief (2017) dan Nuraini Latief (2017), semua menyatakan bahwa motivasi kerja berpengaruh positif dan signifikan terhadap kinerja. Akan tetapi hasil penelitian bertentangan dengan hasil penelitian terdahulu dari Anak Agung et.al (2012); dan Raden Yohanes Luhur (2014), yang membuat kesimpulan bahwa motivasi kerja berpengaruh positif dan tidak signifikan terhadap kinerja. Dari hasil penelitian ini dapat dijelaskan bahwa motivasi kerja pegawai di Sekretariat Daerah Kabupaten Labuhanbatu Selatan secara keseluruhan pada saat ini dalam kategori baik dan dapat meningkatkan kinerja pegawai.

\subsection{Pengaruh Sikap Kerja Terhadap Kinerja Pegawai di Sekretariat Daerah Kabupaten Labuhanbatu Selatan.}

Berdasarkan pada hasil penelitian dapat dijelaskan bahwa sikap kerja berpengaruh positif dan signifikan terhadap kinerja pegawai di Sekretariat Daerah Kabupaten Labuhanbatu Selatan. Hasil penelitian ini sejalan dengan hasil penelitian terdahulu dari Chres F.P Laoh et.al (2016), Famella et.al (2015), Fonny Corryda Rahayu (2013), dan Alias et.al (2018), kesemuanya menyatakan bahwa sikap kerja berpengaruh positif dan signifikan terhadap kinerja. Akan tetapi hasil penelitian bertentangan dengan hasil penelitian terdahulu dari Rd. Kresna et.al (2017), yang membuat kesimpulan bahwa sikap kerja berpengaruh negatif dan tidak signifikan terhadap kinerja. Dari hasil penelitian ini dapat dijelaskan bahwa sikap kerja yang berjalan di Sekretariat Daerah Kabupaten Labuhanbatu Selatan secara keseluruhan pada saat ini dalam kategori baik dan dapat meningkatkan kinerja pegawai.

\subsection{Pengaruh Kepemimpinan \\ Transformasional Terhadap Kinerja Pegawai di Sekretariat Daerah Kabupaten Labuhanbatu Selatan.}

Berdasarkan pada hasil penelitian dapat dijelaskan bahwa kepemimpinan transformasional berpengaruh positif dan signifikan terhadap kinerja pegawai di Sekretariat Daerah Kabupaten Labuhanbatu Selatan. Hasil penelitian ini sejalan dengan hasil penelitian terdahulu dari Apriyanto dan Satrio (2015); Albert Apoi and Hamrila Binti Abdul Latip (2019); Endah Mujiarsih dan Sutrisno, (2003); Yusuf Musa, Sani Danjuma, Fadele Ayotunde Alaba (2018), dan Munawaroh (2011)kesemuanya menyatakan bahwa kepemimpinan transformasional kerja berpengaruh positif dan signifikan terhadap kinerja. Akan tetapi hasil penelitian bertentangan dengan hasil penelitian terdahulu dari Wahyu Budi Priyanto (2016); Weiping Jiang, Xianbo Zhao, Jiangbin Ni (2017), yang membuat kesimpulan bahwa kepemimpinan 
transformasional berpengaruh positif dan tidak signifikan terhadap kinerja. Dari hasil penelitian ini dapat dijelaskan bahwa kepemimpinan transformasional pegawai di Sekretariat Daerah Kabupaten Labuhanbatu Selatan secara keseluruhan pada saat ini dalam kategori baik dan dapat meningkatkan kinerja pegawai.

\subsection{Pengaruh Motivasi Kerja, Sikap Kerja dan Kepemimpinan Transformasional Terhadap Kinerja Pegawai di Sekretariat Daerah Kabupaten Labuhanbatu Selatan.}

Berdasarkan pada hasil penelitian dapat dijelaskan bahwa motivasi kerja, sikap kerja dan kepemimpinan transformasional berpengaruh positif dan signifikan terhadap kinerja pegawai di Sekretariat Daerah Kabupaten Labuhanbatu Selatan. Dari hasil penelitian ini dapat dijelaskan bahwa motivasi kerja, sikap kerja dan kepemimpinan transformasional pegawai di Sekretariat Daerah Kabupaten Labuhanbatu Selatan secara keseluruhan pada saat ini dalam kategori baik dan dapat meningkatkan kinerja pegawai secara bersama-sama.

\section{Kesimpulan}

Dari hasil penelitian dan pembahasan tentang pengaruh motivasi kerja, sikap kerja dan kepemimpinan transformasional terhadap kinerja pegawai pada Sekretariat Daerah Kabupaten Labuhanbatu Selatan, penulis mengambil kesimpulan :

1) Motivasi kerja berpengaruh positif dan signifikan terhadap kinerja pegawai Sekretariat Daerah Kabupaten Labuhanbatu Selatan.

2) Sikap kerja berpengaruh positif dan signifikan terhadap kinerja pegawai Sekretariat Daerah Kabupaten Labuhanbatu Selatan.

3) Kepemimpinan transformasional berpengaruh positif dan signifikan terhadap kinerja pegawai Sekretariat Daerah Kabupaten Labuhanbatu Selatan.

4) Motivasi kerja, sikap kerja dan kepemimpinan transformasional berpengaruh positif dan signifikan terhadap kinerja pegawai Sekretariat Daerah Kabupaten Labuhanbatu Selatan.

\section{DAFTAR PUSTAKA}

A.A. Anwar Prabu Mangkunegara. (2016), Manajemen Sumber Daya Manusia
Perusahaan. Bandung : PT. Remaja Rosdakarya.

Agustini, Fauziah, (2010), Manajemen Sumber Daya Manusia Lanjutan. Medan: Madenatera

Agus Dwiyanto, (2010), Manajemen Pelayanan Publik: Peduli, Inklusif, dan. Kolaboratif. Yogyakarta : Gadjah Mada University Press

Andrew E. Sikula. (2011), Manajemen Sumber Daya Manusia, Erlangga. Bandung

Cepi Priatna (2015), Perilaku Organisasi. PT. Remaja Rosdakarya, Bandung

Davis, Gordon B. (2013), Kerangka Dasar Sistem Informasi Manajemen. Palembang : Maxikom

Dessler, Garry (2011), Manajemen Sumber Daya Manusia, PT. Preshelindo, Jakarta.

Donni Juni Priansa (2011), Perencanaan dan Pengembangan SDM. Penerbit : Alfabeta Bandung

Handoko T, Hani (2013), Manajemen Personalia dan Sumber Daya Manusia, Edisi Kedua, BPFE Yogyakarta.

Hasibuan, Malayu, SP (2013), Manajemen Sumber Daya Manusia, PT. Bumi Akasara Jakarta.

Luthans, Fred. (2014), Perilaku Organisasi, (Alih Bahasa V.A Yuwono, dkk), Edisi Bahasa Indonesia, Yogyakarta.

Marhaeni Fajar (2009), Ilmu komunikasi teori \& praktik, Graha Ilmu, Yogyakarta

Moeheriono, (2014), Pengukuran Kinerja Berbasis Kompetensi Edisi Revisi, PT Raja Grafindo Persada, Jakarta.

Morissan (2013), Teori Komunikasi Individu Hingga Massa, Kencana, Jakarta

Pace, R. Wayne dan Faules. 2015. Komunikasi Organisasi: Strategi Meningkatkan Kinerja Perusahaan. PT. Remaja Rosdakarya, Bandung

Pasolong Harbani, (2013), Kepemimpinan Birokrasi. Bandung : CV.Alfabeta

Prawirosentono, Suryadi. (2011). Kinerja. Bandung: Alfabeta

Rivai, Veithzal dan Sagala, Ella Jauvani. (2009). Manajemen Sumber Daya Manusia Untuk Perusahaan : Dari Teori ke Praktek. Jakarta : PT. Rajagrafindo Persada

Robbins, Stephen. (2015), Organizational Behavior. 9th Edition. New Jersey: Precentice Hall International Inc

Sedarmayanti, (2009). Good Governance (Kepemerintahan Yang Baik), Bandung : Mandar Maju 
(2017), Sumber Daya Manusia dan Produktivitas Kerja. Bandung: CV Mandar Maju

Siagian P. Sondang (2016), Organisasi Kepemimpinan dan Prilaku Organisasi, Gunung Agung Jakarta

Santoso, Singgih. (2012). Panduan Lengkap SPSS Versi 20. Jakarta: PT Elex Media Komputindo

Sugiyono (2014), Metode Penelitian, Erlangga Surabaya

Sudarmanto (2014), Kinerja dan Kompetensi SDM, Yogyakarta, Pustaka Pelajar.

Sulistio, Budi dan Budi, Waspa Kusuma. (2009), Birokrasi Publik (perspektif Ilmu Administrasi Publik). Bandar Lampung: CV. Badranaya

Terry, George R. dalam Afifudin (2013), Dasardasar Manajemen, (Terjemahan: G.A Ticoalu), CV. Alfabeta,Bandung

Wibowo, (2011), Manajemen Kinerja. Cetakan Pertama. Jakarta: Raja Grafindo Persada.

Yulius Eka Agung Saputra (2014), Manajemen Dan Perilaku Organisasi, Graha Ilmu Yogyakarta

\section{Jurnal :}

Alias dan Serling Serdang (2018), Pengaruh Pengetahuan, Sikap Kerja Dan Pengalaman Kerja Terhadap Kinerja Karyawan Kantor BPJS Ketenagakerjaan Cabang Makassar, Jurnal Ilmu Ekonomi, Vol. 1 No. 1, Oktober 2018

Anak Agung Ngurah Bagus Dhermawan I Gde Adnyana Sudibya I Wayan Mudiartha Utama (2012), Pengaruh Motivasi, Lingkungan Kerja, Kompetensi, Dan Kompensasi Terhadap Kepuasan Kerja Dan Kinerja Pegawai Di Lingkungan Kantor Instansi Pekerjaan Umum Provinsi Bali, Jurnal Manajemen, Strategi Bisnis, dan Kewirausahaan Vol. 6, No. 2 Agustus 2012

Efendy, R., Sjahruddin, H., \& Gani, M. (2017). Praktik Motivasi Kerja dan Konsekuensinya Pada Kinerja Aparatur Sipil Negara.ELibrary STIE YPBUP Bongaya 2016 (2)

Endah Mujiarsih dan Sutrisno, (2003), Persepsi Mengenai Gaya Kepemimpinan Transformasional dan Gaya Kepemimpinan Transaksional dan Pengaruhnya Terhadap Upaya Extra (extra effort) Pegawai Instansi Kesehatan Kota (DKK) Semarang, Salatiga, dan Kabupaten Semarang di Ungaran. Jurnal Bisnis dan Ekonomi, Edisi September
Herman Sjaruddin (2019), Pengaruh Kepemimpinan Transformasional dan motivasi terhadap kinerja pegawai STPP Gowa, Jurnal Organisasi dan Manajemen, Isuue 1 (Agustus 2019)

Isman Kadar, Syaiful anwar, Widyatmoko, Wiwiek R (2012), Analisis Kepemimpinan Transformasional, Disiplin, Dan Motivasi Kerja Terhadap Kinerja Pegawai Satpol PP Kota Bogor, Jurnal Universitas Pakuan, Downloads/317-914-1-SM.pdf.

Suparmi. (2010). Pengaruh Kepemimpinan dan Motivasi Kerja Terhadap Kinerja Pegawai pada Dinas Tata Kota dan Permukiman Kota Semarang. Jurnal Media Ekonomi dan Manajemen 